\title{
Immobilization of engineered proteins on a nickel chelating molecular wire
}

\author{
Fabrice Balavoine, ${ }^{\text {a }}$ Anne Girard-Nguyen, ${ }^{\text {a }}$ Patrick Schultz, ${ }^{\text {b }}$ Jacques Haiech, ${ }^{\text {c }}$ and Charles \\ Mioskowski ${ }^{\text {a } *}$ \\ ${ }^{a}$ CEA-Saclay, Service de Marquage Moléculaire et de Chimie Bioorganique, Bâtiment 547, 91191 \\ Gif sur Yvette cedex, France \\ ${ }^{b}$ Institut de Génétique et de Biologie Moléculaire et Cellulaire, 1 rue Laurent Fries, BP163, F- \\ 67404 Illkirch cedex, France \\ ${ }^{c}$ IFR Gilbert Laustriat, Faculté de Pharmacie, 74 route du Rhin, F-67401 Illkirch, France
}

Email: mioskow@aspirine.u-strasbg.fr

\section{Dedicated to Professor Alain Krief on the occasion of his $65^{\text {th }}$ birthday}

\begin{abstract}
Biomolecular nanowires were obtained by assembling proteins onto a linear and conducting polymer: a high molecular weight poly(p-phenyleneethynylene) functionalized with nickel(II) $N$-nitrilotriacetate complexes was found to immobilize histidine-tagged proteins through a specific interaction between nickel complexes and the engineered tags.
\end{abstract}

Keywords: Nanowires, nickel, histidine-tagged proteins

\section{Introduction}

The use of affinity tags that can be genetically engineered at either the amino- or the carboxylterminus of recombinant proteins has been demonstrated to make protein purification significantly easier. One of the most versatile purification methods utilizes the reversible coordination of six consecutive histidine residues (His-tag) to $\mathrm{Ni}^{2+}$ ions immobilized on agarose resins through $N$-nitrilotriacetic acid (NTA) chelating moeities. ${ }^{1}$ Interaction between the Ni-NTA complexes and the His-tag is compatible with a large number of biochemical reagents and His-tags only rarely interfere with the structure and the function of the recombinant protein. Therefore nickel chelating supports appear as general and powerful tools to investigate protein-protein or protein-ligand interactions, to study proteins structures or to develop new biotechnological devices. To date, histidine tagged proteins have been successfully immobilized on gold surfaces, ${ }^{2}$ quartz surfaces, ${ }^{3}$ polystyrene microtiter plates, ${ }^{4}$ polystyrene beads, ${ }^{5}$ and cellulose membranes ${ }^{6}$ functionalized with nickel (II) complexes. 
Synthesis of nickel chelating lipids has allowed immobilization ${ }^{7}$ and two-dimensional crystallization of soluble ${ }^{8}$ and membrane ${ }^{9}$ engineered proteins under a film spread at the air/water interface, helical crystallization of proteins on lipid tubules, ${ }^{10}$ and imaging of proteins by atomic force microscopy. ${ }^{11}$ Herein, we report the preparation of the nickel chelating linear polymer 1, a poly(p-phenyleneethynylene) functionalized with Ni-NTA complexes, and demonstrate its ability to bind histidine-tagged proteins.

\section{Results and Discussion}

Poly( $p$-phenyleneethynylene)s ${ }^{12}$ (pPEs) are polymers often considered as molecular wires because of their rigid and linear П-conjugated backbones. pPEs are usually prepared by coupling dihalogenated $(\mathrm{Br}, \mathrm{I})$ arenes to diethynylated aromatics in Sonogashira conditions ${ }^{13}$ or by acyclic diyne metathesis. ${ }^{14}$ We recently reported conditions allowing highly regioselective condensation of terminal acetylene with 2,5-diiodobenzoic acid. ${ }^{15}$ Using these conditions, a monomer carrying a free alkyne group, an iodide function and a $N$-nitrilotrimethylacetate was prepared (Scheme 1). The latter should lead to the formation of high molecular weight polymers since problems arising from imbalanced stoichiometry of the two reactive functions are avoided.

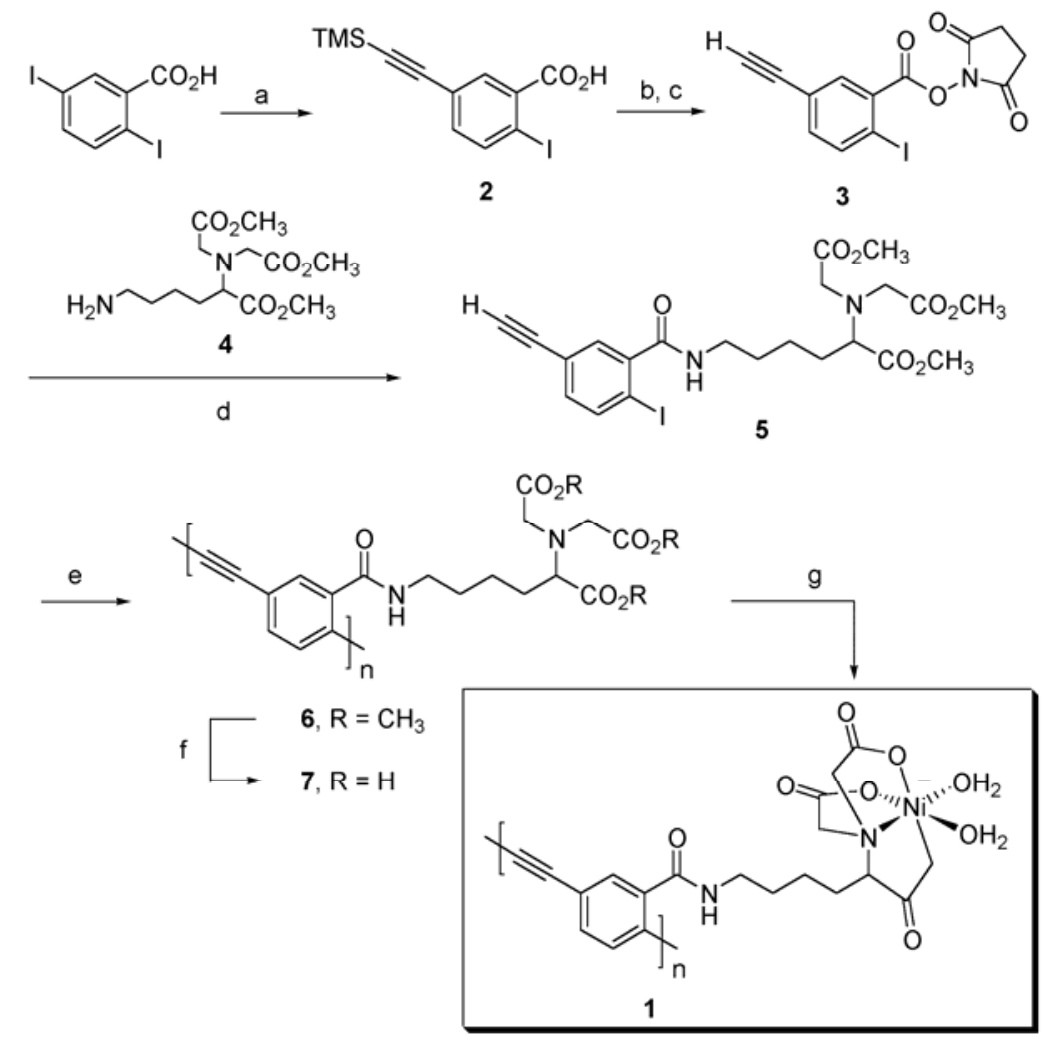

Scheme 1. Synthesis of the nickel chelating molecular wire: (a) TMSA (1.1 eq.), $\mathrm{PdCl}_{2}\left(\mathrm{PPh}_{3}\right)_{2}$ (10\%), CuI (10\%), THF, TEA (73\% yield); (b) KOH, MeOH (97\% yield); (c) DCC, NHS, THF (77\% yield); (d) TEA, $\mathrm{CH}_{2} \mathrm{Cl}_{2}$ (74\% yield); (e) $\mathrm{PdCl}_{2}\left(\mathrm{PPh}_{3}\right)_{2}$ (5\%), CuI (5\%), THF, TEA; (f) $\mathrm{KOH,}$ $\mathrm{MeOH}, \mathrm{H}_{2} \mathrm{O}$ then $\mathrm{HCl}(0.1 \mathrm{~N})$ dropwise until pH 2 (g) $\mathrm{NiCl}_{2} \cdot 6 \mathrm{H}_{2} \mathrm{O}$, Tris-HCl $(10 \mathrm{mM}, \mathrm{pH}=8.0)$. 
When 2,5-diiobenzoic acid is treated at room temperature with 1.1 equivalent of trimethylsilylacetylene in Sonogashira conditions in a mixture of tetrahydrofuran and triethylamine, acid 2 resulting from mono-condensation in the meta-position is isolated. Hydrolysis of the trimethylsilyl group (TMS) and activation of the acid function lead to the $N$ succinimidyl ester $\mathbf{3}$ which can react with the derivative $\mathbf{4}$ to afford the desired iodoaryl acetylene monomer 5. Compound $\mathbf{4}$ is prepared by complete esterification of the corresponding $N$ nitrilotriacetatic analogue elaborated from the Z- $N$-6-lysine as previously described. ${ }^{16}$ The palladium-catalyzed polymerization of $\mathbf{5}$ is performed in a mixture of tetrahydrofuran and triethylamine according to a procedure described earlier ${ }^{17}$ and polymer $\mathbf{6}$ can be isolated.

Inherent insolubility of $\mathbf{6}$ in any common organic solvents has made it very difficult to study and characterize but appeared to facilitate the removal of short oligomers and palladium-containing residues. Solution behaviour of $\mathbf{6}$ is not surprising since poly( $p$-phenyleneethynylene) molecules are usually hardly soluble unless long alkyl or alkyloxy chains are added to the conjugated backbone. However, stirring 6 over 4 days in methanol with an excess of potassium hydroxide leads to complete solubilization, then acidification of the reaction mixture allows polymer $\mathbf{7}$ to precipitate. The degree of polymerization (DP) of 7 could be estimated around 30 by gel permeation chromatography (GPC) performed in a water/acetonitrile mixture. Interestingly, a small fraction of polymers appeared to have much higher molecular weight (DP > 150). Finally, metal chelation was realized in Tris-HCl buffer $(10 \mathrm{mM}, \mathrm{pH}$ 8.0) by stirring polymer 7 with an excess of nickel (II) chloride in a collodion bag with a molecular weight cut off of $12 \mathrm{kDa}$. After dialysis, the nickel chelating poly( $p$-phenyleneethynylene) 1 was used without further purification.

We investigated by gel permeation chromatography the binding ability and the binding specificity of four different histidine-tagged fusion proteins to polymer 1: the shared subunit ABC23 of Saccharomyces Cerevisiae RNA polymerases, ${ }^{18}$ the Bacillus subtilis HPr protein, the thioredoxin-HPr kinase and the thioredoxin-P-Ser-HPr-phosphatase fusion proteins with a His-tag located between the two fused proteins. ${ }^{19}$

Recombinant ABC23 subunit (23kDa) was overexpressed in a yeast strain and purified by affinity chromatography on a 5-ml HiTrapNi column (Pharmacia) with a linear gradient of imidazole. Expressions of $\mathrm{HPr}-\left(\mathrm{His}_{6}\right)$ (16 kDa), thioredoxin-HPr kinase-(His 6 ) (59 kDa) and thioredoxin-P-Ser-HPr-phosphatase-(His ${ }_{6}$ ) (36 kDa) were carried out in E. coli strains and each protein was also purified on Ni-NTA-agarose columns with a gradient of imidazole.

After removing the imidazole present in the protein solutions, the histidine-tagged proteins were incubated under four different conditions and injected onto a superose 6 column: (a) proteins in the absence of polymer $\mathbf{1}$, (b) proteins in the presence of polymer $\mathbf{1}$, (c) proteins in the presence of polymer $\mathbf{1}$ and $300 \mathrm{mM}$ imidazole, (d) proteins in the presence of polymer $\mathbf{1}$ and $300 \mathrm{mM}$ ethylenediaminetetraacetic acid (EDTA). After 15 minutes of elution, fractions were collected in microtubes every minute. The presence of proteins in each fraction was detected by polyacrylamide gel electrophoresis under denaturating conditions, ${ }^{20}$ followed by silver staining or western blotting with specific antibodies. Similar results were obtained with the four different proteins and we report only the data obtained with the thioredoxin-P-Ser-HPr-phosphatase-(His ${ }_{6}$ ) fusion proteins (Figure 1). 


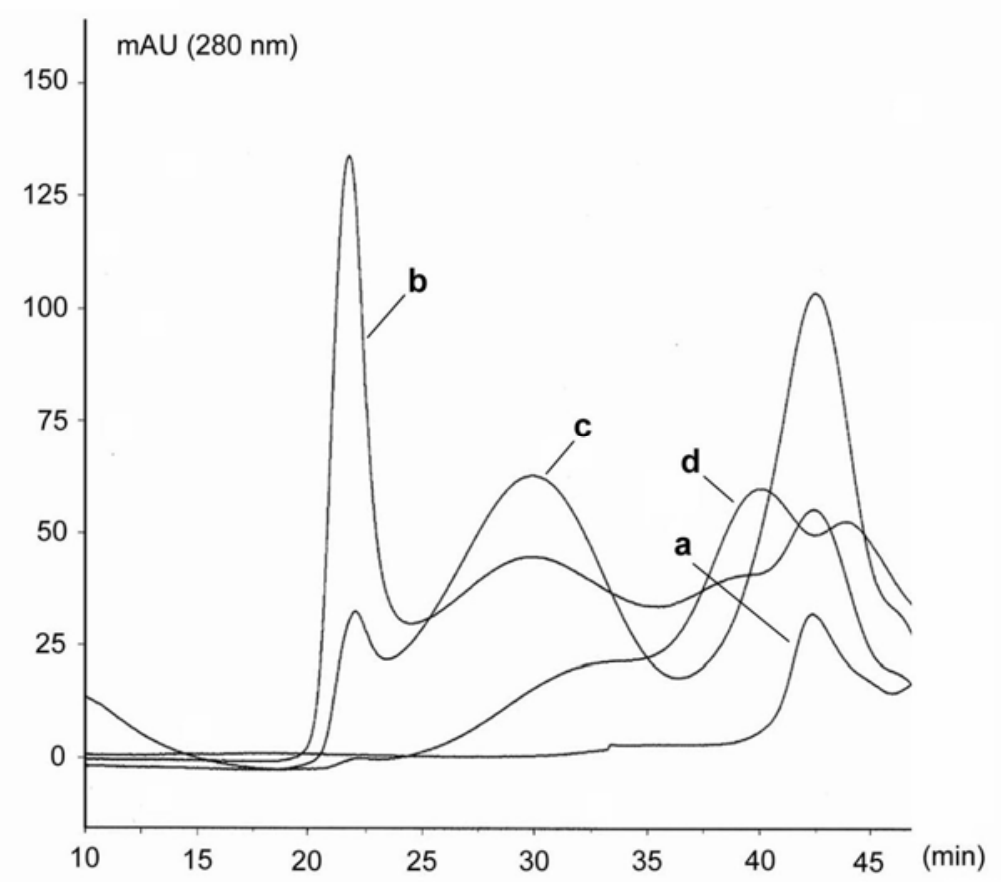

Figure 1. Binding characterization of histidine-tagged thioredoxin-P-Ser-HPr phosphatase fusion proteins on polymer 1 by GPC. $5 \mathrm{nmol}$ of thioredoxin-P-Ser-HPr phosphatases-His ${ }_{6}$ are incubated overnight at $4{ }^{\circ} \mathrm{C}$ with or without polymer 1 (15 nmol of Ni-NTA complexes) and chromatographied on a superose 6 column (a) Thioredoxin-P-Ser-HPr phosphatase-His 6 alone; (b) Thioredoxin-P-Ser-HPr phosphatases-His 6 incubated with polymer 1; (c) Thioredoxin-P-Ser-HPr

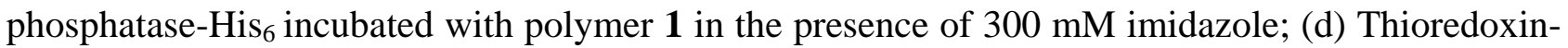
P-Ser-HPr phosphatase-His 6 incubated with polymer 1 in the presence of $300 \mathrm{mM}$ EDTA. Chromatography was performed with a Smart ${ }^{\circledR}$ system (Amersham Pharmacia) (detection $280 \mathrm{~nm}$; elution: Tris-HCl (10 mM, pH 8.0), $\mathrm{NaCl} 150 \mathrm{mM}$; flow: $40 \mu \mathrm{l} / \mathrm{min}$; fraction volume: $40 \mu \mathrm{l}$ ).

When polymer 1 was incubated overnight at $4{ }^{\circ} \mathrm{C}$ with thioredoxin-P-Ser-HPr-phosphatases$\left(\mathrm{His}_{6}\right)$, protein complexes of very high molecular weights could be detected in the exclusion volume of the column. In the presence of polymer 1 most of the proteins are eluted before 24 minutes whereas they are eluted as an homodimer around 42 minutes in the absence of 1 (Figure 1 chromatograms b and a respectively). Column calibration performed in the same conditions showed that $2000 \mathrm{kDa}$ globular proteins are eluted around 27 minutes suggesting that a large number of proteins can be immobilized on a single molecule of $\mathbf{1}$ after an overnight incubation. This long period of incubation might be questionable since immobilization of histidine-tagged proteins on NiNTA resins is known to be complete in less than two hours. However, unlike nickel chelating resins, such rigid and linear polymers present less accessible anchoring sites for protein immobilization. In polymer $\mathbf{1}$, the distance between two functional arms along the conjugated backbone is less than $8 \AA$. In order to bind a large number of proteins, a single molecule of polymer must adapt its structure to minimize steric hindrance between peptide chains. This process may be very slow but may lead to the formation of protein arrays with an helical symmetry around the 
polymer axis. Binding of engineered proteins on polymer $\mathbf{1}$ was also found to be imidazole and EDTA dependent. In the presence of polymer 1 and $300 \mathrm{mM}$ imidazole, thioredoxin-P-Ser-HPrphosphatases-(His 6 ) were detected mainly in the fractions collected between 26 and 33 minutes and in the fractions collected around 42 minutes corresponding to the elution of unbound proteins (Figure 1 - chromatogram c). Imidazole reduces the number of proteins immobilized onto the polymer because imidazole acts as a competitive ligand which prevents the coordination of His-tag to Ni-NTA complexes. Similarly, EDTA has a dramatic effect on the binding of histidine-proteins because EDTA removes nickel ions from polymer 1. In the presence of polymer $\mathbf{1}$ and $300 \mathrm{mM}$ EDTA, thioredoxin-P-Ser-HPr-phosphatases-(His 6 ) were only detected in the fractions collected after 35 minutes and unbound proteins were eluted under a monomeric form around 44 minutes (Figure 1 - chromatogram d).

In conclusion, these results demonstrate that binding of histidine-tagged proteins to polymer $\mathbf{1}$ is not only efficient but also mediated by the interaction between Ni-NTA complexes and His-tags.

Immobilization of thioredoxin-P-Ser-HPr-phosphatase-(His 6 ) fusion proteins on polymer $\mathbf{1}$ was further evidenced by electron microscopy. When aliquots of the elution fraction collected at 22 minutes from chromatogram b (Fig. 1) were adsorbed on a plain carbon coated electron microscopy grid, linear arrangements of proteins could be visualized (Fig. 2).

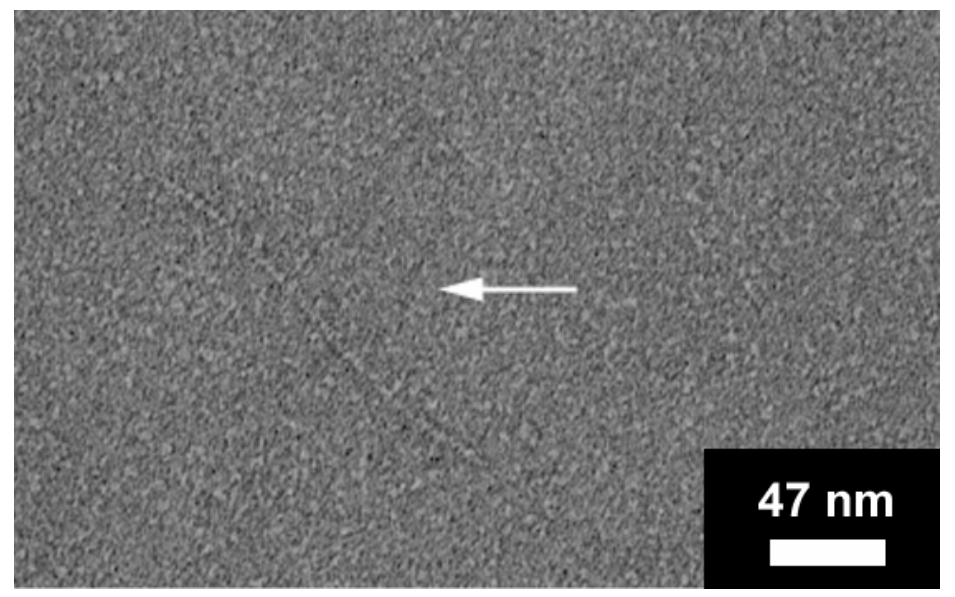

Figure 2. Electron micrograph showing histidine-tagged thioredoxin-P-Ser-HPr phosphatase immobilized on polymer 1. $5 \mu \mathrm{l}$ of the fraction collected at 22 minutes from chromatogram b (see figure 1) were adsorbed on a glow discharge carbon coated electron microscopy grid, negatively stained with a $2 \%$ uranyl acetate solution and observed as previously described. ${ }^{\text {[8d] }}$

The protein arrays which could be localized showed a wide distribution of length ranging from 30 to $180 \mathrm{~nm}$. This size distribution suggests that only arrays induced by the binding of proteins onto polymers with very high molecular weights may be observed. Figure 2 shows a protein arrangement with a length of $170 \mathrm{~nm}$ and a width of $3.2 \mathrm{~nm}$, which should result from the binding of approximately 50 proteins on a single poly( $p$-phenyleneethynylene) molecule. 
In a control experiment, we analyzed by electron microscopy the composition of the fractions collected from chromatograms a, c and d respectively at 42, 29 and 40 minutes. In each case we were unable to visualize such macromolecular structures.

In summary, we have reported a rapid synthetic route for the preparation of monosubstituted poly(p-phenyleneethynylene)s with a backbone built on a head-to-tail linkage of the monomer. It is worth noting that this pathway can be followed for the production of ferromagnetic high-spin molecules. ${ }^{21}$ We have prepared a water soluble poly( $p$-phenyleneethynylene) functionalized with Ni-NTA complexes, capable of binding efficiently histidine-tagged proteins through a specific interaction between the nickel complex and the His-tag of engineered proteins. pPEs display exceptional electronic, ${ }^{22}$ optical $^{23}$ and thermotropic ${ }^{24}$ properties and are particularly of interest in developing molecular scale devices such as light-emitting diiodes, ${ }^{25}$ polarizers, ${ }^{26}$ or chemosensitive antennas. ${ }^{27}$ Yet, these applications have been limited to polymers soluble in organic solvents. To the best of our knowledge, only few syntheses of water-soluble rigid chain polymers has been reported so far in the litterature. ${ }^{28}$ In this report, we have shown that biomolecular nanowires can be built in a water solution, by assembling engineered proteins onto a nickel-chelating pPE scaffold. Interestingly, such assemblies can be generated with a large number of biological systems since it only requires engineering of histidine-tag in a peptide sequence. One can imagine that nickelchelating pPEs will promote the future development of biosensors and bioelectronic nanomaterials, which can take advantage of both the specific biomolecular recognition properties associated with the bound macromolecules and the physical properties of the $\Pi$-conjugated backbone of the polymer. Presently, we are evaluating potential applications of such water-soluble nickel-chelating polymers.

\section{Experimental Section}

General Procedures. All reagents were commercial grade and were used as received without further purification. All reactions were performed under inert atmosphere and anhydrous solvents were dried and distilled over appropriate desiccant prior to use. Thin-Layer chromatograms (TLC) and flash chromatography separations were respectively performed on precoated silica gel 60 F254 plates (Merck, $0.25 \mathrm{~mm}$ ) and on Merck silica gel 60 (230-400 mesh). ${ }^{1} \mathrm{H}$ NMR spectra were recorded on Brucker $\mathrm{AC}-300$ at $300.13 \mathrm{MHz}$ with $\mathrm{CDCl}_{3}(\delta=7.25 \mathrm{ppm})$ as internal standard. ${ }^{13} \mathrm{C}$ NMR spectra were recorded at $75.47 \mathrm{MHz}$ on Bruker AC-300 with $\mathrm{CDCl}_{3}(\delta=77.14 \mathrm{ppm})$ as internal standard. Data are reported as follows: $\mathrm{s}=$ singlet, $\mathrm{d}=$ doublet, $\mathrm{t}=$ triplet, $\mathrm{q}=$ quartet, $\mathrm{m}=$ multiplet. Mass spectra were obtained on a Finnigan-Mat 4600 quadrupole spectrometer using either chemical (DCI-NH3) or electronic (EI-70 eV) ionization mode. UV spectra were acquired with a Victor VPCIIc sytem on a Kontron Uvikon 860 spectrometer. Elemental analyses were performed at the Service de Microanalyse de Gif sur Yvette (France).

\section{Experimental procedures of 2-Iodo-5-trimethylsilanylethynyl-benzoic acid (2)}

To a mixture of $3.74 \mathrm{~g}$ of 2,5-diiodo-benzoic acid (10 mmol, 1 equiv.), $701 \mathrm{mg}$ of dichloro- 
bis(triphenylphosphine) palladium (II) (1 mmol, 0.1 equiv.) and $400 \mathrm{mg}$ of copper (I) iodide (2.1 mmol, 0.21 equiv.) in THF $(120 \mathrm{~mL})$ was added triethylamine $(60 \mathrm{~mL}) .1 .7 \mathrm{~mL}$ of trimethylsilylacetylene (1.186 g, $\mathrm{d}=0.698,12 \mathrm{mmol}, 1.2$ equiv.) were added dropwise and the reaction was stirred overnight at room temperature. The reaction mixture was concentrated in vacuo, resuspended in EtOAc (200mL) and washed with ammonium chloride (10\%) (2 x $200 \mathrm{~mL})$. The organic layer was dried over magnesium sulfate and concentrated in vacuo. Purification of the residue by flash chromatography (Hexane/EtOAc/AcOH: 70/30/1) gave $2.25 \mathrm{~g}$ of 2 as an orange solid (Yield: 73 \%). TLC 0.55 (Hexane/EtOAc/AcOH: 50/50/1). mp: 109-110 ${ }^{\circ} \mathrm{C}$. RMN ${ }^{1} \mathrm{H}(300.13$ MHz, Acetone d6): 10.93 (s broad, 1H), 8.02 (d, J4-5 = 8.2 Hz, 1H), 7.92 (d, J5-7 = 1.8 Hz, 1H), 7.27 (dd, J4-5 = 8.2 Hz, J5-7 = $1.8 \mathrm{~Hz}, 1 \mathrm{H}), 0,25$ (s, 9H). RMN 13C (75.47 MHz, Acetone d6): 166.99, 142.24, 136.85, 135.57, 134.16, 123.75, 103.59, 97.12, 94,52, -0,28 (3C). MS (DCI/NH3): m/z: $362\left(100,[\mathrm{M}+18]^{+}\right)$.

2,5-Dioxo-pyrrolidin-1-yl 2-iodo-5-ethynyl benzoate (3). To a solution of $1.85 \mathrm{~g}$ of 2 (5.38 mmol, 1 equiv.) in methanol (35 mL) was added a solution $1 \mathrm{~N}$ of potassium hydroxide (15 $\mathrm{mL})$. The reaction mixture was stirred $2 \mathrm{~h}$ at room temperature. $1 \mathrm{~N} \mathrm{HCl}$ was added until $\mathrm{pH}=2$ and the product was extracted with methylene chloride $(2 \times 50 \mathrm{~mL})$. The combined organic layers were dried over $\mathrm{MgSO}_{4}$ and concentrated in vacuo to give $1.42 \mathrm{~g}$ of 2-iodo-5-ethynyl-benzoic acid as an orange solid (Yield: $97 \%$ ).

To a solution of $1.2 \mathrm{~g}$ of 2-iodo-5-ethynyl-benzoic acid (4.41 mmol, 1 equiv.) and $558 \mathrm{mg}$ of NHS (4.85 mmol, 1.1 equiv.) in THF (20 mL), 1 g of DCC (4.85 mmol, 1.1 equiv.) in THF (20 mL) were slowly added at $0^{\circ} \mathrm{C}$. The reaction mixture was stirred overnight at room temperature, filtered and concentrated in vacuo. Reprecipitation of the residue from ethanol at $0{ }^{\circ} \mathrm{C}$ afforded $920 \mathrm{mg}$ of $\mathbf{3}$ as a brown solid (Yield: 77 \%). TLC 0,46 (Hexane/EtOAc: 50/50). mp: 200-201 ${ }^{\circ} \mathrm{C}$. RMN ${ }^{1} \mathrm{H}(300.13$ MHz, CDCl3): 8.18 (d, J5-7 = 2.4 Hz, 1H), 8.3 (d, J4-5 = 8.5 Hz 1H), 7.34 (dd, J4-5 = 8.5 Hz, $\left.\mathrm{J}_{5-7}=2.4 \mathrm{~Hz}, 1 \mathrm{H}\right), 3.22$ (s, 1H), 2.91 (s, 4H), RMN 13C (75.47 MHz, CDCl3): 168.53 (2C), 160.49, 141.92, 136.97, 135.09, 129.67, 122.60, 95.60, 80.20 (2C), 25.46 (2C). MS (DCI/NH3): $\mathrm{m} / \mathrm{z}: 387\left(100,[\mathrm{M}+18]^{+}\right), 404\left(31,[\mathrm{M}+35]^{+}\right)$.

Methyl 6-amino-2-(bis-methoxycarbonylethyl-amino)-hexanoate (4). To a solution of $1 \mathrm{~g}$ of 6amino-2-(bis-carboxymethyl-amino)-hexanoic acid ${ }^{16}$ (3,81 mmol, 1 equiv.) in methanol $(50 \mathrm{~mL})$, few drops of concentrated sulfuric acid were added. The reaction mixture was stirred and heated overnight to the reflux of methanol. The reaction mixture was concentrated in vacuo, resuspended in methylene chloride $(50 \mathrm{~mL})$, and successively washed with potassium carbonate $(10 \%)(2 \times 100$ $\mathrm{mL})$ and brine $(50 \mathrm{~mL})$. The organic layer was dried over sodium sulfate and concentrated in vacuo to give $790 \mathrm{mg}$ of 4 as yellow oil (Yield: $68 \%)$. TLC $0.4\left(\mathrm{CHCl}_{3} / \mathrm{MeOH} / \mathrm{TEA}: 80 / 20 / 1\right)$. RMN ${ }^{1} \mathrm{H}$ (300.13 MHz, CDCl3): 3.65 and 3.61 (s, 13H), 3.38 (t, 1H, J2-3 = 7.3 Hz), 2.67 (t, 2H, J5-6 = 6.6 $\mathrm{Hz}$ ), 1.93 (s, 2H), 1.25 - 1.8 (m, 6H). RMN 13C (75.47 MHz, CDCl3): 172.84, 171.53 (2C), 64.51, 52.18 (2C), 51.35 and 51.15 (3C), 41.54 (1C), 32.67, 30.00, 22,90. MS (DCI/NH3): m/z: 305 (100, $\left.[\mathrm{M}+1]^{+}\right)$.

Methyl 2-(bis-methoxycarbonylmethyl-amino)-6-(2-iodo-5-ethynyl-benzoylamino)hexan- oate (5). To a solution of $669 \mathrm{mg}$ of 4 (2.2 mmol, 1.1 equiv.) and triethylamine (1 mL) in methylene 
chloride (20 mL), $738 \mathrm{mg}$ of 3 (2 mmol, 1 equiv.) in methylene chloride (10 mL) were added. The reaction mixture was stirred overnight at room temperature and concentrated in vacuo. Purification of the residue by flash chromatography (Hexane/EtOAc: 60/40) gave $826 \mathrm{mg}$ of 5 as an orange solid (Yield: 74 \%). TLC 0.29 (Hexane/EtOAc: 50/50). RMN 1 $\mathrm{H}$ (300.13 MHz, CDCl3): 7.74 (d, $\left.\mathrm{J}_{15-16}=8.2 \mathrm{~Hz}, 1 \mathrm{H}\right), 7.41$ (d, J16-18 = $\left.2.1 \mathrm{~Hz}, 1 \mathrm{H}\right), 7.09$ (dd, J15-16 = 8.2 Hz, J16-18 = $2.1 \mathrm{~Hz}$, 1H), 6.46 (t, J6-9 = 5.1 Hz, 1H), 3,56 (s, 13H), 3.38 (t, J2-3 = 7.3 Hz, 1H), 3.36 (dt, J5-6 = 6.6 Hz, J6-9 = 5.1 Hz, 2H), 1.40-1.80 (m, 6H). RMN 13C (75.47 MHz, CDCl3): 172.82, 171.54 (2C), 168.42, 142.57, 139.49, 133.54, 131.17, 122.00, 93.04, 81.69, 79.19, 63.95, 52.25 (2C), 51.41 and 51.22 (3C), 39.53, 29.37, 28.08, 22.71. MS (DCI/NH3): m/z: $559\left(100,[\mathrm{M}+1]^{+}\right), 576(36$, $[\mathrm{M}+18]^{+}$). Anal. Calcd. for $\mathrm{C}_{22} \mathrm{H}_{2} \mathrm{IN}_{2} \mathrm{O} 7$ : C 47.32, $\mathrm{H} 4.87, \mathrm{~N}$ 5.02. Found: C 47.01, H 4.95, $\mathrm{N}$ 4.87.

NTA(Me)-pPE polymer (6). To a solution of $84 \mathrm{mg}$ of 5 (0.15 mmol, 1equiv.) in a mixture of THF (6 mL) and triethylamine (2 mL), $11 \mathrm{mg}$ of dichloro-bis(triphenylphosphine) palladium (II) (17 umol, 0.1 equiv.) and 15mg of copper (I) iodide (79 $\mu \mathrm{mol}, 0.5$ equiv.) were quickly added. The reaction medium was stirred at $50{ }^{\circ} \mathrm{C}$ for 48 hours. After returning to room temperature, the reaction medium was poured into $200 \mathrm{~mL}$ of acetone leading to the precipitation of a yellow/orange solid. The solid was recovered by centrifugation of the acetone. The solid was washed thoroughly with acetone $(50 \mathrm{~mL})$ and dichloromethane $(50 \mathrm{~mL})$ and finally dried under vacuo to afford $55 \mathrm{mg}$ of 6 as an orange solid. The solid $\mathbf{6}$ was used without further purification for the next chemical step.

NTA-pPE polymer (7). To a suspension of 6 (34.5 mg) in a mixture of methanol $(8 \mathrm{~mL})$ and water ( $2 \mathrm{~mL}$ ), $400 \mu \mathrm{L}$ of an aqueous solution of potassium hydroxide (1M) were added dropwise. The reaction mixture was stirred at room temperature for 96 hours. The mixture was then filtered and concentrated under vacuo and then taken up in the minimum amount of water. The solution obtained was then reacidified to $\mathrm{pH} 2$ by the slow addition of a $0.1 \mathrm{M}$ hydrochloric acid solution. The yellow precipitate formed was recovered by centrifugation, washed several times with water and then lyophilized to afford $17 \mathrm{mg}$ of 7 as a yellow solid. UV spectrum (in Tris- $\mathrm{HCl}$ (10 mM, pH 8.0); 0.0042 mg/ml): 342 (10531), 298 (9238), 203 (26606)

Ni-NTA-pPE polymer (1). In a collodion bag (molecular weight cut off = $12 \mathrm{kDa}$ ) contaning $2 \mathrm{~mL}$ of a solution of 7 (monomer concentration $=500 \mu \mathrm{M})$ in Tris-HCl $(10 \mathrm{mM}, \mathrm{pH} 8.0), 50 \mu \mathrm{L}$ of a molar solution of nickel (II) chloride hexahydrate were added. After 24 hours of dialysis against a solution of Tris-HCl (10 mM, pH 8.0), collodion bag contents was collected and used as a solution of 1 (monomer concentration $=500 \mu \mathrm{M})$ in Tris- $\mathrm{HCl}(10 \mathrm{mM}, \mathrm{pH} 8.0)$.

\section{Protein binding onto Ni-NTApPE polymer (1)}

Protein preparations were diluted into Tris- $\mathrm{HCl}(10 \mathrm{mM}, \mathrm{pH} 8.0)$ in order to make a $1 \mathrm{mM}$ stock solution. Four different samples of proteins prepared as described below, were incubated at $4^{\circ} \mathrm{C}$ for 24 hours: Sample (a) $=5 \mu \mathrm{L}$ of protein solution ( $1 \mathrm{mM}$ in Tris- $\mathrm{HCl}(10 \mathrm{mM}$, pH 8.0)) plus $45 \mu \mathrm{L}$ of Tris-HCl (10 mM, pH 8.0); Sample (b) $=5 \mu \mathrm{L}$ of protein solution (1 mM in Tris-HCl (10 mM, $\mathrm{pH}$ 8.0)) plus $30 \mu \mathrm{L}$ of polymer 1 solution and $15 \mu \mathrm{L}$ of Tris-HCl (10 mM, pH 8.0); Sample (c) $=5 \mu \mathrm{L}$ of protein solution ( $1 \mathrm{mM}$ in Tris-HCl $(10 \mathrm{mM}, \mathrm{pH}$ 8.0)) plus $30 \mu \mathrm{L}$ of polymer 1 solution and 15 $\mu \mathrm{L}$ of imidazole solution (1M in Tris- $\mathrm{HCl}(10 \mathrm{mM}$, pH 8.0)); Sample (d) $=5 \mu \mathrm{L}$ of protein solution 
(1 mM in Tris-HCl $(10 \mathrm{mM}, \mathrm{pH}$ 8.0)) plus $30 \mu \mathrm{L}$ of polymer 1 solution and $15 \mu \mathrm{L}$ of EDTA solution (1M in Tris-HCl (10 mM, pH 8.0));

All the samples were injected into a Smart System (Amesharm Pharmacia) and analyzed by chromatography through a superpose 6 column (detection $280 \mathrm{~nm}$; elution: Tris-HCl $(10 \mathrm{mM}, \mathrm{pH}$ 8.0), $\mathrm{NaCl} 150 \mathrm{mM}$; flow $40 \mu \mathrm{L} / \mathrm{min}$; fraction volume $40 \mu \mathrm{L})$ ).

\section{Acknowledgements}

We are very grateful to Dr. André Sentenac for providing pure histidine-tagged ABC23 of Saccharomyces Cerevisiae RNA polymerases and to Dr Philippe Mesini for performing GPC experiments. We thank Dr. Laurent Provins for a careful reading and formatting of the manuscript.

\section{References}

1. Höchuli, E.; Bannwarth, W.; Döbeli, H.; Gentz, R.; Stueber, R. Bio/Technology 1988, 6, 1321.

2. (a) Sigal, G. B.; Bamdad, C.; Barberis, A.; Strominger, J.; Whitesides, G.M. Anal. Chem. 1996, 68, 490. (b) Nieba, L.; Nieba-Axmann, S. E.; Persson, A.; Hämäläinen, M.; Edebratt, F.; Hansson, A.; Lidholm, J.; Magnusson, K.; Karlsson, A.F.; Plückthun, A. Anal. Biochem. 1997, 252, 217.

3. Schmid, E. L.; Keller, T. A.; Dienes, Z.; Vogel, H. Anal. Chem. 1997, 69, 1979.

4. Paborsky, L. R.; Dunn, K. E.; Gibbs, C. S.; Dougherty, J. P. Anal. Biochem. 1996, 234, 60.

5. Ho, C.-H.; Limberis, L.; Caldwell, K. D.; Stewart, R. J. Langmuir 1998, 14, 3889.

6. Zaika, A.; Mozzherin, D.J.; Tan, C.-K.; Downey, K.M.; Fisher, P.A. Anal. Biochem. 1999, 268, 193.

7. (a) Dietrich, C.; Boscheinen, O.; Scharf, K.-D.; Schmitt, L.; Tampé, R. Biochemistry 1996, 35, 1100. (b) Dorn, I.T.; Neumaier, K.R.; Tampé, R. J. Am. Chem. Soc. 1998, 120, 2753.

8. (a) Kubalek, E.W.; LeGrice, S.F.J.; Brown, P.O. J. Struct. Biol. 1994, 113, 117. (b) Barklis, E.; McDermott, J.; Wilkens, S.; Schabtach, E.; Schmid, M.F.; Fuller, S.; Karanjia, S.; Love, Z.; Jones, R.; Rui, Y.; Zhao, X.; Thompson, D. EMBO J. 1997, 16, 1199. (c) Vénien-Bryan, C.; Balavoine, F.; Toussaint, B.; Mioskowski, C.; Hewat, E.A.; Helme, B.; Vignais, P.M. J. Mol. Biol. 1997, 274, 687. (d) Bischler, N.; Balavoine, F.; Milkereit, P.; Tschochner, H.; Mioskowski, C.; Schultz, P. Biophys. J. 1997, 74, 1522. (e) Barklis, E.; McDermott, J.; Wilkens, S.; Fuller, S.; Thompson, D. J. Biol. Chem. 1998, 273, 7177.

9. Levy, D.; Mosser, G.; Lambert, O.; Moeck, G.S.; Bald, D.; Rigaud, J.-L. J. Struct. Biol. 1999, $127,44$.

10. Wilson-Kubalek, E.M.; Brown, R.E.; Célia, H.; Milligan, R.A. Proc. Natl. Acad. Sci. USA. 1998, 95, 8040. 
11. (a) Dorn, I.T.; Hofmann, U.G.; Peltonen, J.; Tampé, R. Langmuir 1998, 14, 4836. (b) Dorn, I.T.; Eschrich, R.; Seemuller, E.; Guckenberger, R.; Tampé, R. J. Mol. Biol. 1999, 288, 1027.

12. Giesa, R.J. Macromol. Sci., Rev. Macromol. Chem. Phys. 1996, C-36, 631.

13. Sonogashira, K.; Tohda, Y.; Hagihara, N. Tetrahedron Lett. 1975, 50, 4467.

14. (a) Kloppenburg, L.; Jones, D.; Bunz, U. H. F. Macromolecules 1999, 32, 4194. (b) Kloppenburg, L.; Song, D.; Bunz, U. H. F. J. Am. Chem. Soc. 1998, 120, 7973.

15. Balavoine, F.; Madec, D.; Mioskowski, C. Tetrahedron Lett. 1999, 40, 8351.

16. Höchuli, E.; Döbeli, H.; Schacher, A. J. Chromatogr. 1987, 411, 177.

17. Swager, T. M.; Gill, C. J.; Wrighton, M. S. J. Phys. Chem. 1995, 99, 4886.

18. Lanzendörfer, M.; Smid, A.; Klinger, C.; Schultz, P.; Sentenac, A.; Carles, C.; Riva, M. Genes Dev. 1997, 11, 1047.

19. Galinier, A.; Kravanja, M.; Engelmann, R.; Hengstenberg, W.; Kilhoffer, M.-C.; Deutscher, J.; Haiech, J. Proc. Natl. Acad. Sci. USA. 1998, 95, 1823.

20. Laemmli, U. K. Nature 1970, 277, 680.

21. Nishide, H.; Maeda, T.; Oyaizu, K.; Tsuchida, E. J. Org. Chem. 1999, 64, 7129.

22. (a) Yamamoto, T.; Takagi, M.; Kizu, K.; Maruyama, T.; Kubota, K.; Kambara, H.; Kurihara, T.; Kaino, T. J. Chem. Soc., Chem. Commun. 1993, 9, 797. (b) Weder, C.; Wrighton, M. Macromolecules 1996, 29, 5157. (c) Hirohata, M.; Tada, K.; Kawai, T.; Yoshino, K. Synth. Met. 1997, 85, 1273.

23. (a) Moroni, M.; Lemoigne, J.; Pham, A.; Bigot, J.-Y. Macromolecules 1997, 30, 1964. (b) Weder, C.; Wrighton, M. S.; Spreiter, R.; Brosshard, C.; Gunter, P. J. Phys. Chem. 1996, 100, 18931.

24. Kloppenburg, L.; Jones, D.; Claridge, J. B.; zur Loye, H.-C.; Bunz, U. H. F. Macromolecules 1999, 32, 4460.

25. Kraft, A.; Grimsdale, A. D.; Holmes, A. B. Angew. Chem., Int. Ed. Engl. 1998, 37, 402.

26. (a) Eglin, M.; Montali, A.; Palmans, A. R. A.; Tervoort, T.; Smith, P.; Weder, C. J. Mater. Chem. 1999, 9, 2221. (b) Montali, A.; Bastiaansen, C.; Smith, P.; Weder, C. Nature 1998, 392, 261.

27. Zhou, Q.; Swager, T. M. J. Am. Chem. Soc. 1995, 117, 12593.

28. (a) Wallow, T. I.; Novak, B. M. J. Am. Chem. Soc. 1991, 113, 7411. (b) Patil, A. O.; Ikenoue, Y.; Wudl, F.; Heeger, A. J. J. Am. Chem. Soc. 1987, 109, 1858. (c) McCullough, R. D.; Ewbank, P. C.; Loewe, R. S. J. Am. Chem. Soc. 1997, 119, 633. 